\title{
An Introduction to SWATH GRAZING in Western Canada
}

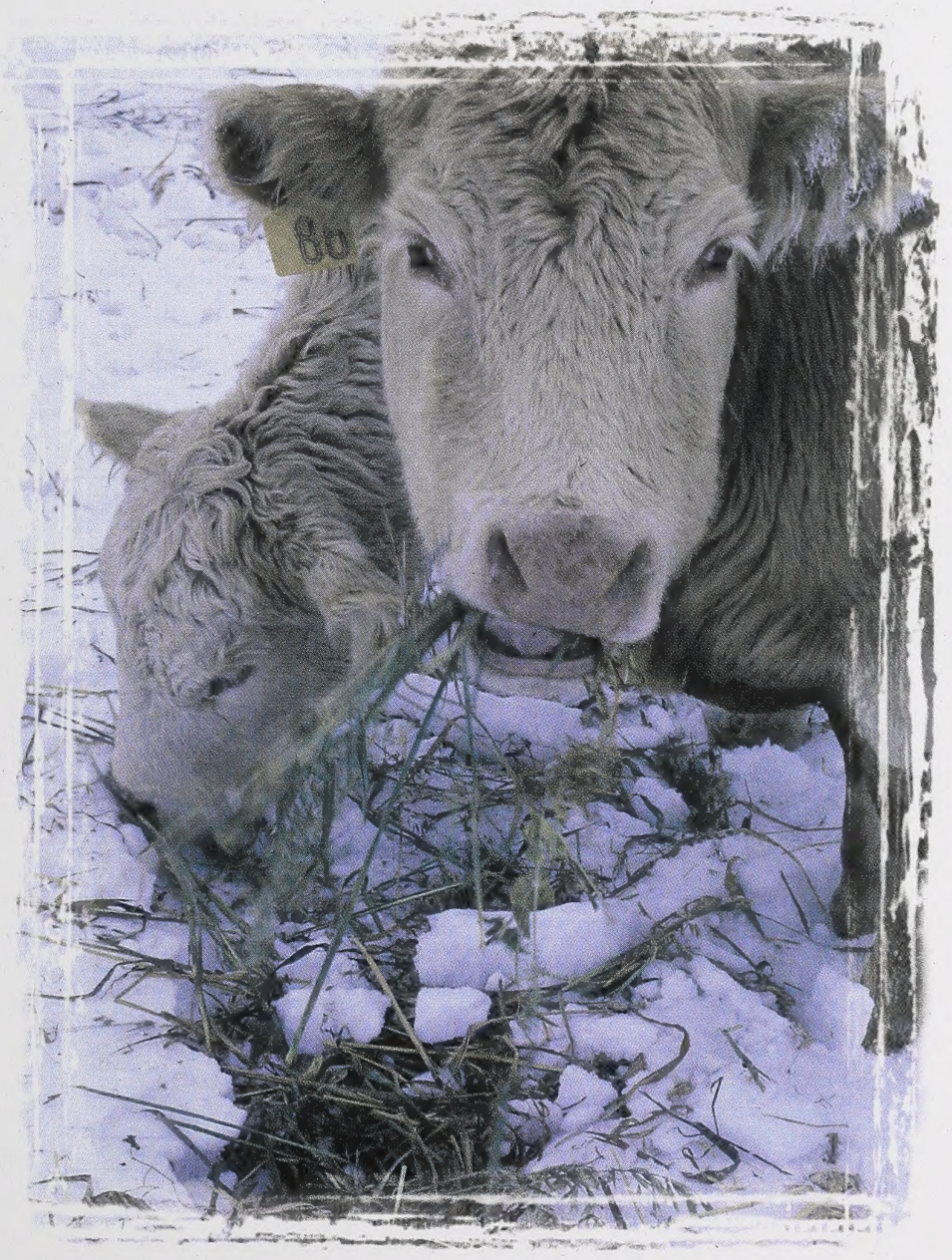

Agdex 420/56-1

\section{Alberta


Digitized by the Internet Archive in 2015

https://archive.org/details/introductiontosw00albe 


\section{An Introduction to SWATH GRAZING in Western Canada}

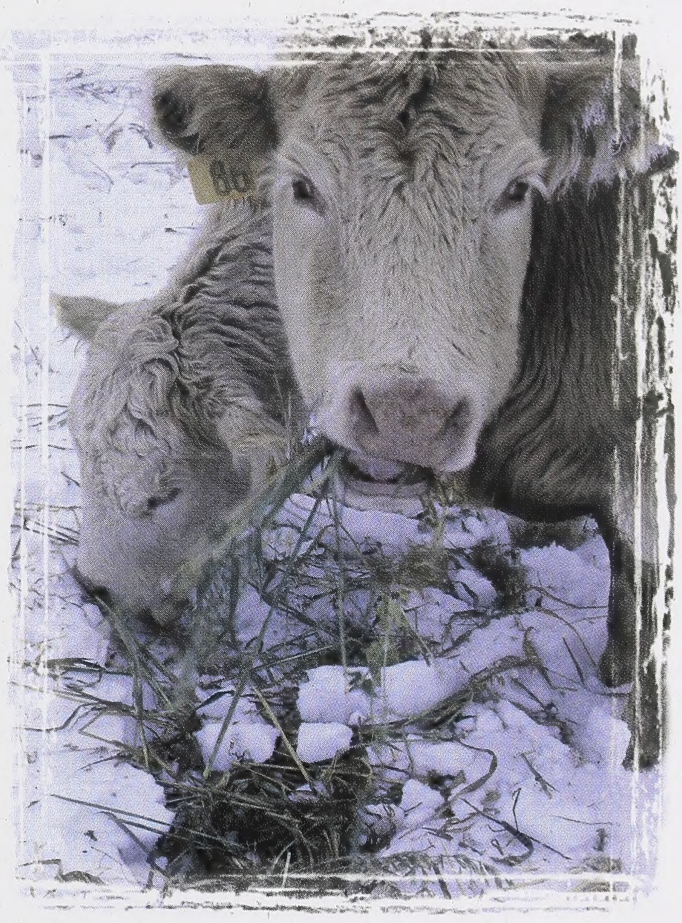




\section{Published by}

Alberta Agriculture, Food and Rural Development 7000-113 Street

Edmonton, Alberta T6H 5T6

Copyright 1998. All rights reserved by her Majesty the Queen in the Right of Alberta.

Reproduction of up to 100 copies for classroom use by non-profit organizations or photocopying of single copies is permitted. All other reproduction (including storage in an electronic retrieval system) requires written permission from the Publishing Branch, Alberta Agriculture, Food and Rural Development.

\section{Copies of this publication are available from:}

Your local Alberta Agriculture, Food and Rural Development office

OR:

Publishing Branch

Alberta Agriculture, Food and Rural Development 7000-113 Street

Edmonton, Alberta T6H 5T6

Edited by: Ground Words

This publication is a co-operative project by Alberta Agriculture, Food and Rural Development's Conservation and Development Branch, Animal Industry Division and Regional Advisory Services; the Western Forage/Beef Group; the Grey Wooded Forage Association; and, the Gateway Research Organization. Funds for production were provided by: Alberta Agriculture, Food and Rural Development's Animal Industry Division; Alberta Environmentally Sustainable Agriculture Program; Western Forage/Beef Group; and, Agriculture and Agri-Food Canada, Lacombe.

Printed in Canada 


\section{Contents}

\begin{tabular}{|c|c|}
\hline Introduction & 5 \\
\hline Selecting cattle for swath grazing & 6 \\
\hline Choosing a field & 6 \\
\hline Annual crops & 6 \\
\hline Seeding an annual crop & 6 \\
\hline Fertilizer rates & 6 \\
\hline Herbicides & 7 \\
\hline Swathing & 7 \\
\hline Perennial crops & 7 \\
\hline Testing swath quality & 7 \\
\hline Grazing management & 8 \\
\hline Supplemental feed & 8 \\
\hline Estimating days of available feed & 8 \\
\hline Grazing through snow & 9 \\
\hline Fencing & 9 \\
\hline Grounding & 9 \\
\hline Energizers & 9 \\
\hline Polywire & 9 \\
\hline Fence posts & 10 \\
\hline Snow as a water source & 10 \\
\hline Managing swath residue & 10 \\
\hline Managing manure & 11 \\
\hline Wildlife considerations & 11 \\
\hline Swath grazing research results & 12 \\
\hline Economics of swath grazing & 13 \\
\hline Summary & 15 \\
\hline References and information sources & 15 \\
\hline
\end{tabular}




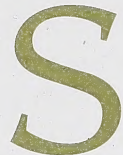

wath grazing is a management technique that's growing in popularity with cattle producers in Western Canada. Late-seeded annuals are swathed in mid-September in the soft dough stage and left for cattle to graze during the winter. Allowing livestock to obtain all or part of their feed through swath grazing extends the grazing season and reduces winter feed costs. Potential environmental benefits such as residue and manure management exist when swath grazing. It may also eliminate or reduce the cost of corral cleaning and manure spreading.

The results from a recent survey of over 100 producers conducted by Alberta Agriculture, Food and Rural Development and Saskatchewan Agriculture and Food are incorporated throughout this publication. The majority of surveyed producers said the biggest advantages of swath grazing were reduced costs and time savings. Swath grazing reduced the cost of harvesting forage, and machinery use for handling feed and manure.

For swath grazing to be successful, good management is necessary. This includes diligently applying livestock management principles so the cattle are healthy and maintain adequate condition. Feed, fencing, water sources and shelter are all important elements that need to be carefully planned when developing a swath grazing program. This publication describes the management practices you need to consider to ensure that winter swath grazing is done successfully without sacrificing cattle health and productivity.

Swath grazing can reduce feed costs, labor costs and manure handling.

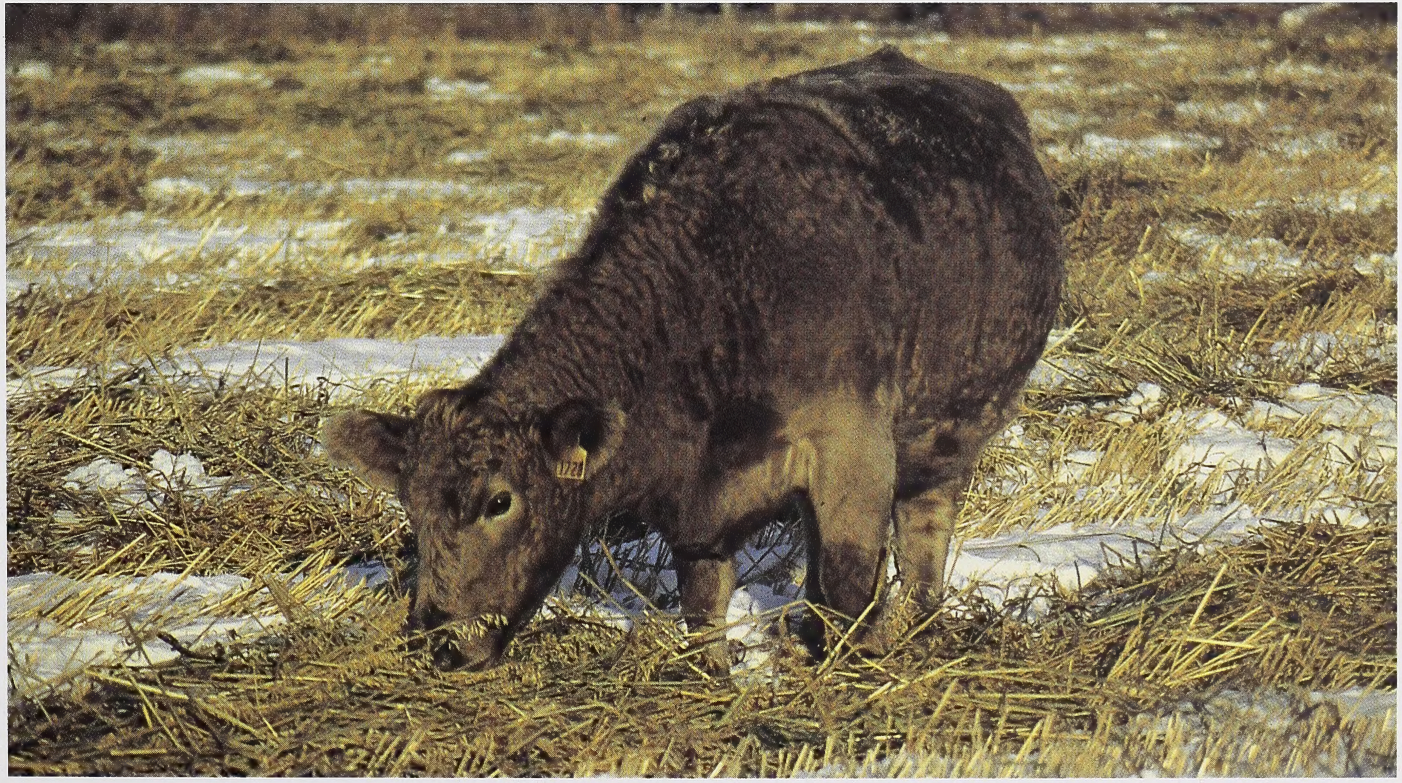




\section{Selecting cattle for swath grazing}

The first step in planning a swath grazing program is to select appropriate animals. Most producers are using swath grazing to feed dry, mature beef cows in reasonable body condition.

Caution is required when swath grazing calves, young cows, thin cows and cows with calves, as they need higher levels of energy and management, and more quality feed than mature dry cows. If swath grazing these types of animals, consider providing them with supplemental feed and shelter. The condition of your cattle after swath grazing influences the productive capability of the herd in the long run.

\section{Choosing a field}

Many factors come into play when selecting the right type of field to use for a swath grazing program. Fields close to farm buildings and water sources are the best sites for swath grazing. Field characteristics influence the potential length of the grazing season, animal health issues and the time you spend managing the herd. For best results, select a field:

- with protection from the wind. Swath grazing animals spend more time and energy eating than those on conventional feeding programs. A natural or portable wind break is necessary for adverse weather;

- where you can supplement feed to the animals on cold, windy days when the animals are not as willing to go out and eat the swaths;

- where you can easily monitor animal condition and remove any animals that are not doing well;

- where a water system is nearby if snow is unavailable or unsuitable as a water source; and

- where access to windrows is not limited due to severe snow drifting.

\section{Annual crops}

Barley and oats are the most common crops used for swath grazing. Producers and researchers have found that high yielding grain varieties generally produce higher forage yields. Later maturing forage type varieties are also recommended. For the best crop variety, check the Annual Crop Variety factsheet available from your provincial agriculture department.

If using barley for swath grazing, smooth awned varieties are preferred, as rough barley awns may lodge in a cow's mouth and cause lesions.

Oats or barley can be mixed with spring-seeded winter cereals such as fall rye and winter triticale. One of the benefits of using such a mixture is the increased swath quality because of the winter cereal's leafy nature and regrowth after swathing. The regrowth continues well into the fall, and cattle will graze it first before starting on the swaths. The winter annuals are also available for grazing again the following spring.

\section{Seeding an annual crop}

It is best to delay seeding cereal crops until late June or early July. By delaying seeding, the crop is at the soft dough or earlier stages of maturity when swathed in the fall. A crop in the soft dough stage provides a high quality forage.

When mixing winter cereals with spring crops, the winter cereal should be planted according to moisture levels for your area. Winter triticale and winter wheat are less hardy than fall rye and often show signs of winter kill.

For maximum forage yield, cereal seeding rates should be increased by 25 per cent over those rates used for grain production to ensure stand density. When mixing barley and oats, vary the seeding rate according to the amount of each crop wanted in the stand.

\section{Fertilizer rates}

Normal fertilizer rates used for grain crops should be adequate for a swath grazing program. A soil test should be conducted to determine the optimum level of nutrients needed. 
Excess nitrates from heavily fertilized or manured fields might accumulate in plants that are under stress from drought or exposed to long periods of cool, cloudy weather or early frosts. If the stress is removed and the plants recover, nitrate levels should return to normal within several days. The incidence of nitrate problems in Western Canada is very low.

\section{Herbicides}

Weeds can be more easily controlled under a swath grazing system because delayed seeding allows extra time to control weeds that emerge before seeding. If broadleaf weed control is required, use a recommended herbicide. It is important to check the herbicide label for grazing and feeding restrictions.

\section{Swathing}

The swath should lay on top of the stubble and be as narrow and deep as possible. Barley should be swathed at or before the soft dough stage and oats at or just before the milk stage to ensure a high quality feed. You should swath late enough in the fall so cool daytime temperatures prevent mold growth on the swaths. If a heavy frost occurs, it is best to cut the crop as soon as possible. In the event that a damaged mature crop has to be salvaged through swath grazing, great care must be taken to prevent grain overload. Cows will often concentrate on eating the mature grain heads first, so their access to the swaths must be limited.

\section{Perennial crops}

Currently some producers are experimenting with perennial crop regrowth for swath grazing. However, winter kill could be a problem because swath grazing may leave the perennial crop with insufficient snow cover. This swath grazing practice is uncommon.
Take several samples to assess feed quality.

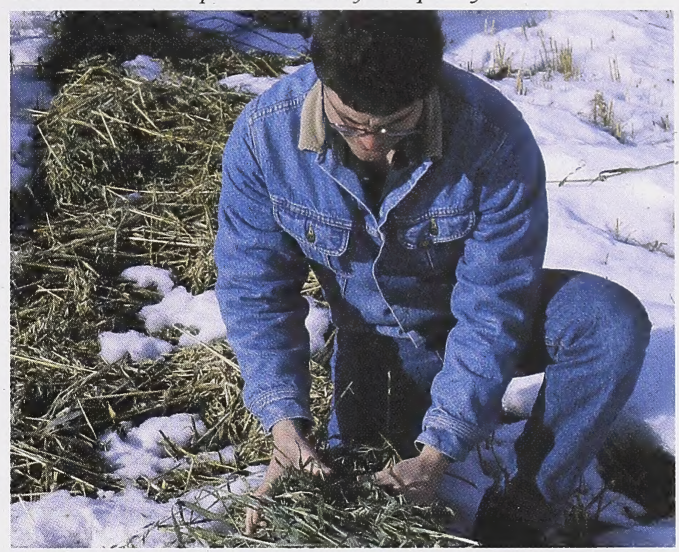

\section{Testing swath quality}

It is important to know the feed quality of the swath to estimate the nutrition levels available and determine the type and amount of supplemental feed needed.

The accuracy of the feed test depends on the number of samples taken. It is best to take several random samples from across the field. The combined sample must be representative of the crop being grazed. If there are differences in large areas of the field, consider submitting separate samples from those parts of the field.

The sample can be analyzed at any accredited laboratory. The analysis should include fibre content, projected energy levels, protein levels, calcium, phosphorus and possibly nitrate levels. The results can then be used to balance the ration.

Producers have expressed concerns about high nitrate levels in their swaths. Feeds containing high nitrate levels can be fed on a controlled basis. High nitrate levels can occur on highly fertilized soil if a drought or a major frost occurs prior to swathing. To maintain quality and minimize the risk of a nitrate buildup in the feed, swath the crop before the major killing frost or immediately following. An Alberta Agriculture, Food and Rural Development factsheet titled Nitrate Poisoning and Feeding Nitrate Feeds to Livestock provides more information on this subject. 


\section{Grazing management}

Controlling cattle access to the swaths is cited by producers as one of the most challenging and important factors to swath grazing. Animals are forced to clean up the swath when they are confined to a small area. If cattle are not confined they will eat the grain heads first, which may cause grain overload. This leaves only the straw for the remainder of the winter grazing period which results in periods of inadequate nutrition.

One way to prevent free access to the entire swath grazing area is to use a portable electric fence. This improves feed utilization, prevents the snow from packing, regulates the quantity of feed being consumed, and minimizes wastage.

Depending on weather and management practices, feed usage from swath grazing can be as high as or higher than the usage of harvested hay or silage crops. Harvesting and storage losses of hay and silage can be as high as 30 per cent. Feeding losses of stored feed in winter pens are at least 10 to 20 per cent.

\section{Supplemental feed}

It is essential to closely monitor your herd for body condition and health. Supplemental feed may be necessary during periods of cold temperatures and heavy snow falls. Minerals and salt should always be available.

\section{Estimating days of available feed}

To estimate the days of available feed, calculate the area of the field and the yield, and estimate utilization of the swaths. To estimate swath utilization, assume a cow will utilize four to five per cent of its body weight, taking into account feed wastage. Thus a 1,200 pound cow uses about 60 pounds of swath feed per day. The length of the swath grazing season is affected by how well the cows clean up the swath, which is influenced by snow depth. The thoroughness of consumption can be difficult to estimate.

Table 1 is an example of a swath grazing program conducted at the Melfort Research Station in Saskatchewan. In this situation, they found the swaths that were not utilized during the winter swath grazing period were completely consumed by the cows and calves the following spring.

Table 1

Oats Swath Grazing at Melfort Research Station

\section{Grazing Cows \\ Days /Acre (dry matter lb/acre) Consumption (lb/cow)}

\begin{tabular}{|c|c|c|c|c|}
\hline Nov. 3 to Dec. $21 / 94$ & 48 & 2.6 & 7179 & 57.9 \\
\hline Noy. $21 / 95$ to Jan. $8 / 96$ & 48 & 2.25 & 6750 & 62.5 \\
\hline Nov. $21 / 96$ to Jan. $9 / 97$ & 48 & 2.25 & 7624 & 70.6 \\
\hline
\end{tabular}


Crusted snow can make grazing difficult.

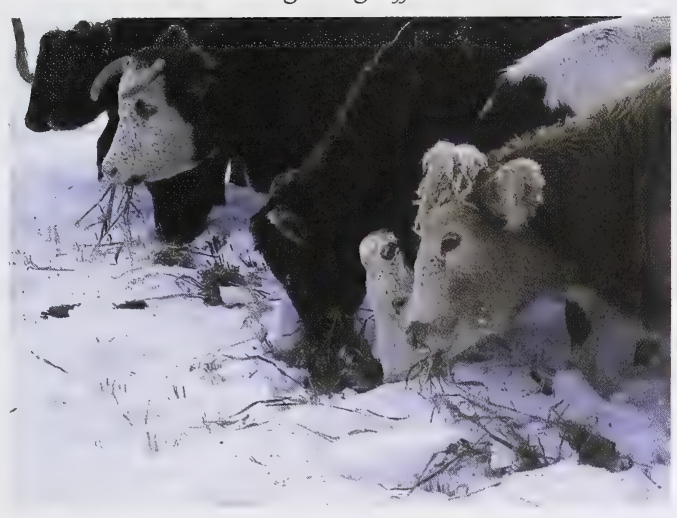

\section{Grazing through snow}

Cows can graze through two feet of soft snow. Wind-swept or severely crusted snow make grazing difficult or impossible. If the snow is too hard or crystallized, the animal's nose becomes tender and lower leg hair can be rubbed off. If this happens, remove the herd from the swaths.

If the snow becomes too hard or too deep, it may be physically impossible for the herd to access the swath. Some ways to help open up the swath in times of heavy snow include driving a tractor down the swath or blading snow off the swath. Placing a portable fence across the swaths also helps by exposing the ends of the swath as the cows will see the continuation of the swath after each fence move.

If you plan on using a field that has low lying areas and other places where snow accumulates, have the cattle graze these areas earlier in the winter.

\section{Fencing}

A temporary electric fence is the easiest and cheapest way to control cattle access to swaths. Once cattle learn to respect an electric fence, they will not challenge it to get at the other swaths. Fences should be placed at a right angle to the swaths.

\section{Grounding}

Proper grounding is critical to making an electric fence work. The high insulating factor of snow and frost often restricts the fence's ability to deliver a shock to the livestock. To overcome this, build a two-wire fence where one wire is electrified and one is grounded. Contact local suppliers or check manuals on fencing for more information on grounding electric fences.

\section{Energizers}

Energizer type also plays a role in the effectiveness of an electric fence. A 110 volt energizer is recommended for reliability and low maintenance. Battery-powered energizers can be used, but need to be checked as they often need recharging. A heavy duty, deep cycle battery should be used. Put the battery in an insulated box for further protection and longer use.

If using a solar-powered fence, watch for snow cover on panels and the availability of sunlight. Check frequently to see if there is adequate power, especially when daylight is short, and always keep backup batteries available.

\section{Polywire}

Strength and visibility are the reasons for using polywire or polytape. Check for durability, as some polytape and polywire can break down from prolonged exposure to ultraviolet light and cold temperatures. 


\section{Fence posts}

Many different kinds of materials can be used for fence posts. Rebar and fiberglass posts are often used because of their durability in winter. When using rebar, be aware that a short occurs if the electrified wire touches the rebar, and then the rest of the fence becomes less effective.

Planning post placement before winter freeze-up saves time. Portable fences must be sturdy for use on swath grazing fields. A small cordless drill with an extension bit can be used to drill a hole to set the post in frozen ground. When setting posts, you may find there is less frost underneath the swaths than between swaths. To remove rebar posts easily, turn the post several times with a small pipe wrench.

Fence at right angle to swaths.

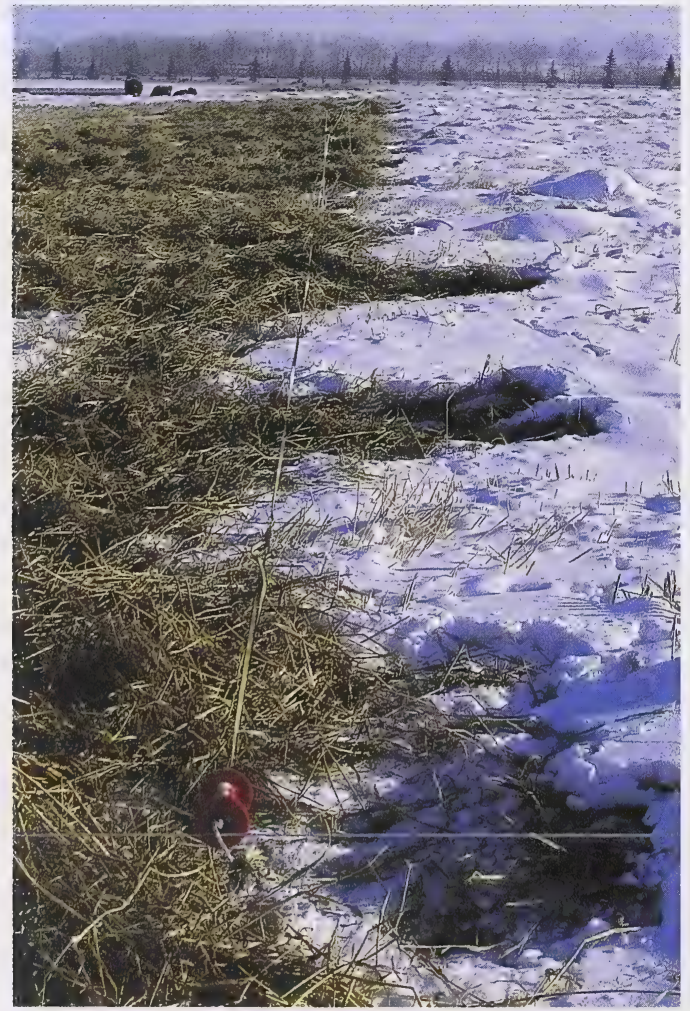

\section{Snow as a water source}

Cattle prefer water, but snow can be an adequate water source. Cattle that are unfamiliar with using snow as a water source will start to consume snow within one to three days. Cattle recover quickly from this adjustment.

Cattle prefer clean, soft snow. Snow from areas that have been trampled, wind blown or crusted is not a reliable water source. In Chinook areas, lack of snowfall and periodic melting make snow an unpredictable water source. Snow trapping may help meet the herd's water needs in these areas.

Whether you decide to use snow alone or a combination of snow and fresh water, monitor your animals closely to determine if their water needs are being met. If cattle show signs of distress from lack of water, provide an alternative water source.

The University of Alberta has conducted several studies using snow as a water source for cattle. Pregnant cows using snow as their only water source showed only a minimal difference in their calf's body mass, subcutaneous fat, birth weight or weaning weight. However, lactating cows and their calves need to have access to a water source, since they often lose body weight when consuming snow.

\section{Managing swath residue}

Swath grazing can result in crop residue carryover due to field losses. The amount of residue left in the field depends on the length of the grazing period, snow or ice accumulation, windrow access, stocking rates and animal distribution. If the levels of residue are significant, extra field work, such as cultivating or harrowing, may be required before seeding the next crop. The following steps can be used to reduce residue carryover from swath grazing:

- Make swaths as narrow and as deep as possible when cutting the crop. Narrow windrows result in livestock spreading out in the field instead of concentrating on one swath. This reduces losses due to trampling and bedding by the livestock. 
- Restrict the amount of swath available to livestock. Smaller areas result in more uniform consumption of the swaths.

- Consider adding supplemental feed on top of old swath material to encourage clean-up before moving cattle to a new grazing site.

- Before winter, bale areas where access may be limited. Baled feed can be fed if weather restricts swath grazing.

If crop residue remains in the spring, consider the following options:

- Regraze the fields during early spring while they are still frozen, or after they have dried enough to adequately support livestock. Soil compaction can occur in wet conditions.

- Rake the windrows in the spring prior to regrazing. This will enhance the level of clean-up during spring grazing.

- Bale any unused swath material in the spring. This material can be used in the next winter feeding period.

- Use harrows to spread small amounts of crop residue and livestock manure. Additional harrowing or cultivation may be required to manage large amounts of residue:

\section{- Remember that cattle require supplemental feed when cleaning up the residue.}

\section{Managing manure}

On average, a 1,000 pound cow produces 50 to 60 pounds of manure and urine per day. Since swath grazing forces the cattle out on the field during the day, manure deposited during that time is distributed on the land. This reduces the amount of manure to be hauled out during the spring, lowering manpower and equipment costs. There is less odor and runoff because less manure is concentrated in a confined area.

Caution must be taken when bedding animals in treed areas. Cattle bedding in treed areas will deposit high amounts of manure and urine there, which results in less nutrients on the crop land and more pollution problems. Collecting the manure from the treed area is often difficult.

Consider using portable windbreaks to encourage the cows to bed on the fields. Periodic movement of the portable windbreaks allows the manure to be deposited on the land and minimizes accumulations in any one spot. Spring field work can then be done without problems due to excess manure accumulation.

\section{Wildlife considerations}

It is important to assess potential conflicts with wildlife before swath grazing. Deer and elk can trample feed and defecate on fields left for swath grazing. The severity of the winter and the amount of native feed available, influence what deer and elk choose as a feed source. Deer and

Periodically moving portable shelters avoids high manure accumulations in any one spot.

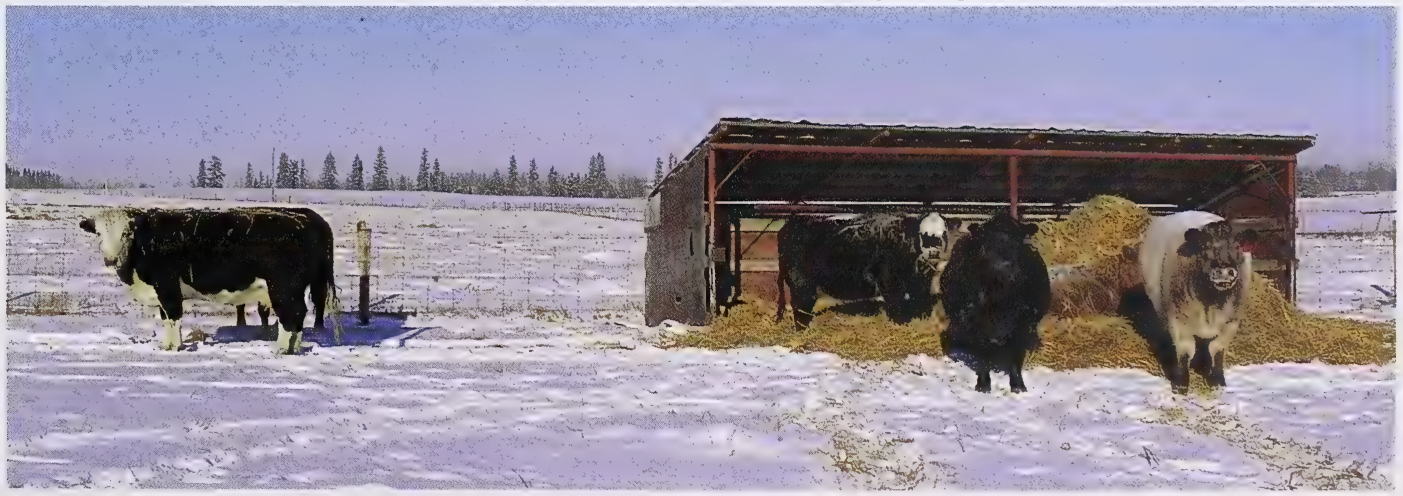


elk prefer oat swaths over barley swaths, therefore swath grazing barley may discourage deer and elk from eating the swath. If expected losses from wildlife are great, other feeding systems should be considered. Wildlife was a problem for 23 per cent of the producers surveyed, and most problems occurred in the Grey and Black soil zones.

Wildlife can also cause problems by walking on ungrazed swaths. This trampling packs and seals the snow, forming a heavy crust that prevents cattle from accessing the swath. Reduce trampling by wildlife by selecting a site close to home or a field that can be easily monitored.

Try to scare the deer and elk away at the start of swath grazing before they get into the habit of eating swaths. Local Fish and Wildlife officers may be able to suggest acceptable scaring methods. Allowing hunting on fields that are to be swath grazed may scare the deer and elk away at least temporarily. Install a high electrified perimeter fence or multiple fences early in the season to discourage wildlife from entering the field. Be aware that elk and moose can knock down portable fencing units.

\section{Swath grazing research results}

A three-year swath grazing study was conducted at the Agriculture and Agri-Food Canada Research Station at Melfort, Saskatchewan. Oats were seeded in late June and swathed in the soft dough stage in mid-September. Half of the cow herd (Charolais, Hereford and Angus-cross cows) was allocated to swath grazing in November. The balance of the herd was fed free choice straw supplemented with oat silage and grain. All cows had access to sheltered wintering pens, water and minerals.

Cows were weighed and evaluated for body condition at the start and conclusion of the grazing period. No major problems were encountered, and cows on swath grazing were in similar condition to those on stored feed at the end of the grazing trial, as illustrated in Table 2. Cows calved in late February and March. In April and early May, the cows and calves grazed the remaining swathed materials. During this time, they were also fed their daily post-calving ration. All crop residue was consumed by the animals, but soil compaction was a problem due to wet conditions in the spring. As a result, extra tillage was required at seeding time but no adverse effects were noted in the following crop.

\section{Table 2}

\section{Cow Performance, Swath Grazed vs. Fed in Pens, Melfort Research Station, 1994-96 (48 days, Nov. - Jan.)}

\begin{tabular}{lccc} 
& \multicolumn{3}{c}{ Average Daily Gain (lb) } \\
& 1994 & 1995 & 1996 \\
\hline Swath Grazed & 1.34 & 0.75 & 0.66 \\
\hline Fed in Pens & 0.26 & 0.84 & 0.75
\end{tabular}

Final Body Condition Score*

\begin{tabular}{lccc} 
Swath Grazed & 3.0 & 3.0 & 3.0 \\
\hline Fed in Pens & 3.0 & 3.0 & 3.0
\end{tabular}

*score ranges from 1 for very thin to 5 for very fat 
Table 3

Oats Swath Quality, Melfort Research Station, Winter 1995-96

\begin{tabular}{lccc} 
Date & Protein (\%) & ${ }^{*}$ ADF (\%) & ${ }^{* * N D F ~(\%)}$ \\
\hline Sept. 20/95 & 10.97 & 31.5 & 52.1 \\
\hline Oct. 6/95 & 11.32 & 34.7 & 65.4 \\
\hline Nov. 11/95 & 11.59 & 39.2 & 66.2 \\
\hline Dec. 6/95 & 11.06 & 40.7 & 68.6 \\
\hline Dec. 20/95 & 10.63 & 43.3 & 63.7 \\
\hline Jan. 2/96 & 11.03 & 38.6 & \\
*ADF: Acid detergent fibre ** NDF: Neutral detergent fibre & & &
\end{tabular}

Source: Western Forage/Beef Group 1998

The cows in this swath grazing program did as well as animals on stored feed. The quality of the swathed material was adequate over the swath grazing period, as illustrated by Table 3 . Based on these results, swath grazing is a viable feeding practice.

\section{Economics of swath grazing}

The surveyed producers used a variety of management techniques for swath grazing. This makes it difficult to estimate savings due to lower labor requirements in cattle feeding. There are some areas where swath grazing could result in substantial savings. Swath grazing can reduce or eliminate the cost of baling, hauling and stacking forage. It also eliminates or reduces the cost of chopping, hauling and packing silage. However to utilize the entire crop, the fields will need to be regrazed the following spring. Swath grazing may also eliminate or reduce the cost of corral cleaning and manure spreading.

Swath grazing could also be compared to grain production. However, this may not be realistic as the late seeding dates used in swath grazing make a grain harvest unlikely. Table 4 lists some of the factors to consider when comparing swath grazing to greenfeed or silage costs. Some of the cost information is based on the 1996 Farm Operations Cost Guide, from Alberta Agriculture, Food and Rural Development. 
Table 4

Comparing swath grazing with other winter feeding costs

\begin{tabular}{lll} 
Swath Grazing & Silage & Greenfeed or Hay \\
\hline Less manure handling & $\begin{array}{l}\text { Conventional manure handling. } \\
\text { Custom rates for corral } \\
\text { cleaning and spreading } \\
\text { (1 loader, 2 spreader trucks, } \\
3 \text { operators) range from } \\
\$ 120 / \text { hour to } \$ 170 / \text { hour }\end{array}$ & $\begin{array}{l}\text { Conventional manure handling. } \\
\text { Custom rates for corral } \\
\text { cleaning and spreading } \\
\text { (1 loader, 2 spreader trucks, } \\
3 \text { operators) range from } \\
\$ 120 / \text { hour to } \$ 170 / \text { hour }\end{array}$ \\
& $\begin{array}{ll}\text { Cost of chopping and hauling } \\
\text { silage. Custom rates for } \\
\text { silage chopping and hauling } \\
\text { range from } \$ 6 / \text { ton to } \$ 9 / \text { ton }\end{array}$ & $\begin{array}{l}\text { Cost of baling and hauling } \\
\text { greenfeed or hay. Custom } \\
\text { rates for baling, hauling and } \\
\text { stacking range from } \$ 9 / \mathrm{bale} \\
\text { to } \$ 11.50 / \mathrm{bale}\end{array}$ \\
& &
\end{tabular}

Lower labor costs; labor

General wintering costs

General wintering costs

distributed over the year, not

in high season

\begin{tabular}{lll}
\hline Little or no feed storage costs & Feed storage costs & Feed storage costs \\
\hline $\begin{array}{l}\text { Residue in field may be } \\
\text { higher, thus increased } \\
\text { harrowing or cultivation costs }\end{array}$ & $\begin{array}{l}\text { Normal harrowing or } \\
\text { cultivation costs }\end{array}$ & $\begin{array}{l}\text { Normal harrowing or } \\
\text { cultivation costs }\end{array}$ \\
\hline $\begin{array}{l}\text { Cost of checking cattle and } \\
\text { moving electric fence }\end{array}$ & $\begin{array}{l}\text { Cost of feeding (e.g. labor, } \\
\text { equipment, corrals) }\end{array}$ & $\begin{array}{l}\text { Cost of feeding (e.g. labor, } \\
\text { equipment, corrals) }\end{array}$ \\
\hline $\begin{array}{l}\text { Yield loss on day started to } \\
\text { swath graze }\end{array}$ & $\begin{array}{l}\text { Loss during field operations, } \\
\text { hauling and storage }\end{array}$ & $\begin{array}{l}\text { Loss during field operations, } \\
\text { hauling and storage }\end{array}$ \\
\hline Bedding costs & Bedding costs & Bedding costs
\end{tabular}

Watering costs may be

higher if installing additional

watering for grazing

Electric fencing costs Pen maintenance costs Pents

Less disease (e.g. scours)

because animals are not

confined to one area

Extend the grazing season More time in feedlot More time in feedlot

Access to swaths in winter is

limited by snow conditions 


\section{Summarry}

Swath grazing is a viable option for many livestock producers. It offers the potential to reduce feed costs, labor costs and manure handling. As with any new management practice, creating a successful swath grazing program requires planning. Carefully assess field characteristics, animal condition and your options for crops, water sources, shelter, fencing, residue management and manure management. The viability of swath grazing is largely dependent on local conditions, snow depth and wildlife problems, and you need to assess the economic feasibility for your own situation.

Monitoring your animals during swath grazing is essential. Diligent livestock management principles need to be applied to keep your animals healthy. Supplemental feed may be necessary during periods of cold temperatures and heavy snowfalls.

By planning, and following the guidelines described in this publication, you can begin a swath grazing program suitable for your farming operation. Consulting with a livestock or forage grazing specialist will also be helpful in developing a long term grazing strategy.

\section{References and information sources}

The information for this publication was developed from the following publications and the experience of over 100 producers who participated in the 1997 Swath Grazing Survey prepared by Alberta Agriculture, Food and Rural Development, and Saskatchewan Agriculture and Food.

Klein, L., Winter Grazing and Alternative Feeds for Beef Cattle in Saskatchewan. Grazing and Pasture Technology Program, Regina, Saskatchewan, 1994.

Klein, L., Winter Swath Grazing. Grazing and Pasture Technology Program, Regina, Saskatchewan, 1996.

McCartney, D., Research Summary of Swath Grazing. Western Forage/Beef Group, Agriculture and Agri-Food Canada, Lacombe, Alberta, 1996.

McCaughey, W.P., Winter Swath Grazing in Manitoba. Agriculture and Agri-Food Canada, Research Centre, Brandon, Manitoba, 1996.

Young, B.A., Tennessen, T., Degen, A.A.; Liveweight of Individually Fed Beef Cows Receiving Snow or Liquid Water. 59th Annual Feeders' Day Report. University of Alberta, 1980, pp. 57-59.

Young, B.A., Tennessen, T., Degen, A.A., Liveweight and Behavioural Responses in Cattle Ingesting Snow as their Water Source. 59th Annual Feeders' Day Report. University of Alberta, 1980, pp. 60-61.

Young, B.A., Tennessen, T., Effect of Snow as a Water Source on Beef Cows and their Calf Production. Canadian Journal of Animal Science, 1991, $71(2)$ : 585-588. 


\section{For more information}

The following publications offer information to help you plan a swath grazing program. If you require further information on swath grazing, contact your local forage or grazing association or a livestock or forage grazing specialist.

\section{Swath grazing using annual crops:}

Varieties of Cereal and Oilseed Crops for Alberta, Alberta Agriculture, Food and Rural Development, Agdex 100/32.

Winter Cereals for Pasture, Alberta Agriculture, Food and Rural Development, Agdex 133/20-1.

Varieties of Grain Crops 1997, 1997 Saskatchewan Seed Guide, Saskatchewan Agriculture and Food.

A Guide to Management Intensive Grazing, Managing Grazing for Better Results, Manitoba Agriculture, January 1997.

An Introduction to Management Intensive Grazing, Growing for Tomorrow, Manitoba Agriculture, October 1996.

Pasture Management, Forage Facts, Manitoba Agriculture, Agdex 130-101.

Managing Crops on Peat Soils, Soil Facts, Manitoba Agriculture, Agdex 518.

Rotational Grazing, The Rest and Recovery Method of Pasture Management, Conservation Facts, Manitoba Agriculture, October 1995.

Snow as a water source:

Pasture Pumping Systems, Growing for Tomorrow, Manitoba Agriculture, October 1995.
Fertilizer rates:

Alberta Fertilizer Guide, Alberta Agriculture, Food and Rural Development, Agdex 541-1.

General Recommendations for Fertilization in Saskatchewan, Saskatchewan Agriculture and Food, Agdex 541.

Fertilizing Alfalfa Forage, Soil Facts, Manitoba Agriculture, Agdex 541.

Nitrate Poisoning and Feeding Nitrate Feeds to Livestock, Alberta Agriculture, Food and Rural Development, Agdex 400/60-1.

Nitrogen Fixation and Legumes in Crop Rotation, Soil Facts, Manitoba Agriculture, Agdex 537/121.

Fencing:

Fencing with Electricity, Alberta Agriculture, Food and Rural Development, Agdex 724-6.

Fencing Costs, Farm Facts, Saskatchewan Agriculture and Food, February 1996.

Guidelines for Estimating Farm Fencing Costs, Manitoba Agriculture, February 1992.

Body Condition Scoring:

Body Condition: Implications for Managing Beef Cows, Alberta Agriculture, Food and Rural Development, Agdex 420/40-1 

Bibliothèque nationale du Canada

33286513563839 